\title{
ムライトセラミックスの曲げ強度に及ぼす欠陥の影響
}

\author{
吉田 秀人, 宮田昇, 山岸千丈
}

日本セメント㧣中央研究所, 干135 江東区清澄1-2-23.

\section{Influence of Defect on the Bending Strength of Mullite Ceramics}

\author{
Hideto Yoshida, Noboru Miyata and Chitake Yamagishi
}

Central Research Laboratory, Nihon Cement Co., Ltd., 1-2-23 Koto-ku, Tokyo 135.

Received April 20, 1994

Relation between three point bending strength of mullite ceramics and their defects is studied. From SEM analysis of specimens after three point bending test, origin of fracture was mainly due to pores exsisting in specimens. Position of pores depended on specimens and shapes of pores were irregular shapes. Stresses loaded on defects are about $80 \sim 90 \%$ of bending strengths. Experimental equation of the relation between stress and defect is $\sigma=1420 / \mathrm{C}^{1 / 2}$, while $\sigma=1070 / \mathrm{C}^{1 / 2}$ is obtained by Griffith's theoretical equation in case of sphere defect. Maximum main stress is calculated by FEM on the assumption that shape of defect are oval (radius ratio: a/b). The maximum main stress of oval defect changed about $\pm 30 \%$ in comparison with that of sphere defect in the range of $\mathrm{a} / \mathrm{b}=0.5 \sim 2.0$.

\section{1 緒言}

$\mathrm{SiC}, \mathrm{Si}_{3} \mathrm{~N}_{4}$ ，ムライト等のセラミックスは，耐酸 化性，耐熱性に優れるため， $1000^{\circ} \mathrm{C}$ 以上で使用でき る構造材料として多くの研究が進められている11.

材料の機械的特性の一つである破壊強度は, 引張 試験や曲げ試験等で測定されるが，セラミックスの 場合，試料作製や測定が容易な，曲げ試験で評価さ れることが多い，一般にセラミックス材料の破壊強 度は，試験片ごとのバラツキが金属材料に比べて大 きい.これは，セラミックスのような脆性材料では，
材料中にポア，加工傷，龟裂等の小さな欠陥が多数 存在しており，これら久陷近傍部での応力集中によ り，材料の破壊強度が決まること，および試料ごと に欠陷の大きさが異なるためと考えられる，グリフ ィスは，ガラス等の脆性材料の破壊強度が薢裂長さ の1/2乗に逆比例することを示した2).

ところで，JIS の 3点曲げ試験で曲げ強度を測 定する場合には，破壊源となる久陌が荷重直下部の 最大引張応力の発生点に存在すると仮定して計算す るので，仮定と異なる位圆に欠宿が存在すれば，実 
際に欠陥に働く応力は，小さくなる．従って，3点 曲げ試験でセラミックスの曲げ強度を测定する場合 には，予め曲げ強度と欠宿の位置に㗢く応力との関 係を検討しておく必要がある，そこで，本研究では， 高温構造材料として期待されるムライトセラミック スをとりあげ，その3点曲げ強度と欠宿に㗢く応力 の関係，欠陥の大きさと欠陷に㗢く応力の関係及び 欠宿形状の曲げ強度に及ぼす影響について検討した。

\section{2 試料作製および特性評価}

\section{1 試料作製}

平均粒径の異なる 2 種の高純度ムライト粉末（A : 平均粒径 $0.3 \mu \mathrm{m}, \mathrm{B}$ : 平均粒径 $0.17 \mu \mathrm{m}$ 日本七 メント製) を粉碎後，整粒しプレス成形（31MPa）, C I P (196MPa) 処理を行い, $1630^{\circ} \mathrm{C}$ 大気中で 4 時 間焼成し，得られた焼結体を研削後， $3 \times 4 \times 40 \mathrm{~mm}$ の試験片（A：38本，B：36本）に切断することに より試料 $A ， B$ を作製した。

\section{2 特性評価}

焼結体の相対密度と気孔率は，アルキメデス法に よる高密度の測定値とムライトの理論密度 $3.15 \mathrm{~g} /$ $\mathrm{cm}^{3}$ より求めた，焼結体の曲け強度 $\left(\sigma_{3 \mathrm{p}}\right)$ は， 3 点曲げ試験（クロスヘット速度 $0.5 \mathrm{~mm} / \mathrm{min}$ ）時に得られ る最大荷重値を用いて，(1)式で求めた。

$$
\begin{aligned}
& \sigma_{3 \mathrm{P}}=3 \cdot \mathrm{P} \cdot \mathrm{L} /\left(2 \cdot \mathrm{w} \cdot \mathrm{d}^{2}\right) \\
& \mathrm{P}: \text { 最大荷重 }(\mathrm{N}) \\
& \mathrm{W}: \text { 試験片幅 }(\mathrm{mm}) \\
& \mathrm{d}: \text { スパン長さ }(30 \mathrm{~mm})
\end{aligned}
$$

㩐結体の破壊鞋性は，IF法（ビッカース圧子荷重 $5 \mathrm{Kg}$ ）で測定した，曲げ試験後の試料の破壊位置及 びその大きさは，走査型電子顕徽鏡（SEM 日立 製 S-405）を用いて測定し，破壊位置は，Fig.1に 示す，荷重負荷直下部の引張り面を原点とし，横方 向の変位を $\mathrm{X}$ 座標，上方向をY座標として求めた。
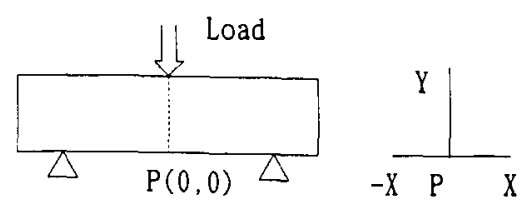

Fig. I Co-ordinates at bending test.

また，表面部にある破壊源を表面破壊，内部にあ る破壊源を内部破壊と定義した。なお，3点曲げ武
験時の破壊源のX方向の分布は，（2）式で得られ る位置 $\mathrm{x}$ での破壊源の存在割合Pで整理した。

$$
\begin{aligned}
& \mathrm{P}(\mathrm{x})=\mathrm{S}(\mathrm{x}) / \int \mathrm{S}(\mathrm{x}) \mathrm{d} \mathrm{x} \\
& \mathrm{S}(\mathrm{x})=(\mathrm{m}+1) \cdot(\mathrm{L}-\mathrm{x})^{\mathrm{m}} /(\mathrm{L})^{\mathrm{m}+1} \\
& \mathrm{~m}: \text { ワイブル係数 } \quad \mathrm{L}: \text { スパン長さの半分 }
\end{aligned}
$$

\section{3 破壊位置での态力計算}

曲げ試験後のS E M 観察で, 破壊源位置が判明し た試料について，曲げ強度之破壊位置を用い，破壊 部に発生する応力を，ミニコン（日本DEC製： $\mu$ VAX 3600）を用いた有限要素法（日本マーク製：MARC） による応力解析で求め，得られた破壊源位置に作用 する応力を破壊応力とした。なお，計算結果をグリ フィスの式と比較するため，表面破壊の試料に対し て, 破買源形状を半球と仮定し，(3)式のグリフィ スの式で破壊源にかかる応力（ $\left.\sigma_{8}\right)$ を計算した。

（3）式の応力拡大係数には，破壊靬性值の実測值 を用いた。

$$
\sigma_{g}=\mathrm{K} /(\pi \cdot \mathrm{c})^{1 / 2}
$$

$\sigma_{\mathrm{g}}$ ：破壊源にかかる応力（MPa） $\mathrm{c}$ ：破壊源径(m) $\mathrm{K}$ : 応力桩大係数 $\left(\mathrm{MPam}^{1 / 2}\right)$

\section{3. 実験結果及び考察}

\section{1 ムライト焼䊅体の諸特性}

\begin{tabular}{|c|c|c|}
\hline Characteristics & A & $\mathrm{B}$ \\
\hline Open Porosity $\quad(\%)$ & 0.54 & 0.07 \\
\hline Relative Density $(\%)$ & 97 & 99 \\
\hline Bending Strength (MPa) & 275 & 313 \\
\hline We ibul Modulus $\quad(-)$ & 13 & 6 \\
\hline Fracture Toughness (MPam ${ }^{1 / 2}$ ) & 1. 9 & 1. 9 \\
\hline
\end{tabular}

Table 1 に試料A 之試料 Bの各気孔率, 相対密度, 常温 3 点曲げ強度，ワイブル係数および破壊靱性を， Fig. 1 に試料A， Bの各ワイブルプロットを示す. Table 1より，試料A，Bとも，気孔が少なく相対

Table 1 Physical and mechanical properties of mullite $A$ and mullite $B$.

密度の大きな焼結体であり, 平均粒径の小さい粉末 で作製した試料 Bの方がより緻密化していた。試料 A，Bの機械的特性を比較すると，曲げ強度は，試 


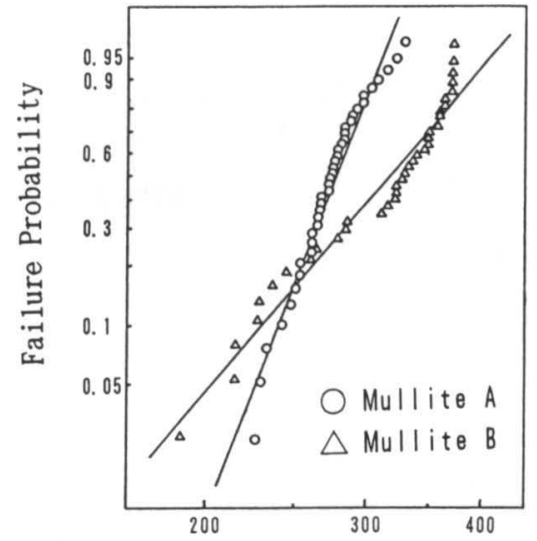

Bending Strength ( $\mathrm{MPa})$

Fig. 2 Weibull Plot of Mullite $A$ and Mullite $B$ 料 B に比べ試料 $\mathrm{A}$ の方が低かった。試料 B の曲げ強 度が, 試料 $\mathrm{A} の$ 曲げ強度に較へて高かったのは, 微 細な原料粉末を使用したため, より緻密化したため と考えられる。但し，ワイブル係数は，試料 Aの方

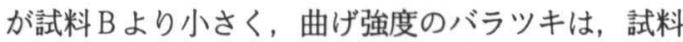
Aの方が大きかった。 また, 破壊靱性は, 試料 $\mathrm{A}$, $\mathrm{B}$ とも同じであり，原料粉末の破壊靱性に対する影 響はなかった，次に，曲げ試験後の試料の S E M 観 察により，破壊原因を検討した，Photo. 1 に，試料 Aの表面部に見られる破壊源の例を, Table 2 に， S E M 観察により求めた破壊源の位置, 表面破壊と 内部破壊の区別, 破壊源の大きさ (半径) ならびに

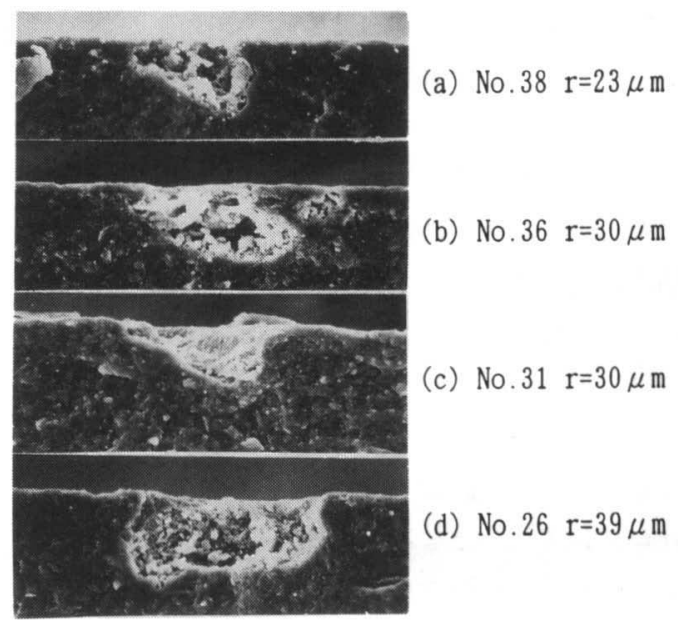

Photo. 1 SEM photographs of tracture origins of mullite ceramic A.
3 点曲げ強度を示す. Photo.1では, 試料中に散在 するポアが破壊源になったと考えられ，その断面形 状は，不定形であり，棈円形に近い形状である，試 料Aでは，曲げ試験における破壊原因を特定できた ものは，38の試験片のうち 37 試験片であり，す べての破壊原因は，Photo.1に示すようなポアであ った. Table 2 より，各試験片の破壊源位置は，曲 げ試験時の引張面の表面部に 24 点存在し，表面よ り少し内部に入った部分で 13 点見いだされた，破 壊源を表面破壊，内部破壊に分け，各破壊源別にワ イブル係数，平均強度を求めてみると，どちらの值 もほぼ同じであった。

Table 2 Pore Position, Pore size and Bending

\begin{tabular}{|c|c|c|c|c|c|c|}
\hline No. & $\underset{(\mathrm{mm})}{\operatorname{Pore}}$ & $\begin{array}{c}\text { Pos it ic } \\
\text { Y } \\
\text { (mm) }\end{array}$ & & $\begin{array}{l}\text { Pore } \\
\text { size } \\
(\mu \mathrm{m})\end{array}$ & $\begin{array}{l}\text { Bending } \\
\text { Strength } \\
\text { (MPa) }\end{array}$ & $\begin{array}{l}\text { Stress on } \\
\text { the Pore } \\
(\mathrm{MPa})\end{array}$ \\
\hline 1 & 0.8 & 0.35 & $i$ & 47 & 226 & 180 \\
\hline 2 & 1.2 & 0 & $s$ & 55 & 226 & 204 \\
\hline 3 & 1.3 & 0 & $s$ & 48 & 229 & 204 \\
\hline 4 & 0.4 & 0.4 & i & 30 & 238 & 181 \\
\hline 5 & 0.7 & 0 & $s$ & 66 & 243 & 225 \\
\hline 6 & 1.8 & 0 & $s$ & 48 & 246 & 211 \\
\hline 7 & 0.4 & 0 & $s$ & 33 & 248 & 233 \\
\hline 8 & 2.9 & 0.006 & i & 39 & 248 & 195 \\
\hline 9 & 0.4 & 0 & $s$ & 36 & 256 & 241 \\
\hline 10 & 0.3 & 0 & $s$ & 42 & 256 & 242 \\
\hline 11 & 0.6 & 0 & $s$ & 51 & 256 & 239 \\
\hline 12 & 0.3 & 0 & $s$ & 51 & 260 & 245 \\
\hline 13 & & 0.005 & i & 15 & 260 & 229 \\
\hline 14 & 0.1 & 0 & $s$ & 30 & 261 & 247 \\
\hline 15 & 0.7 & 0 & $s$ & 45 & 262 & 243 \\
\hline 16 & 1.2 & 0.002 & $\mathrm{i}$ & 12 & 262 & 236 \\
\hline 17 & 0.8 & 0 & $s$ & 30 & 267 & 247 \\
\hline 18 & 0.9 & 0.003 & i & 24 & 267 & 246 \\
\hline 19 & 0.3 & 0 & $s$ & - & 268 & - \\
\hline 20 & 1.0 & 0 & $s$ & 60 & 269 & 246 \\
\hline 21 & 0.8 & 0 & $s$ & 42 & 270 & 250 \\
\hline 22 & 1.7 & 0.02 & i & 33 & 271 & 235 \\
\hline 23 & 3.7 & 0 & $s$ & 69 & 273 & 195 \\
\hline 24 & 5.0 & 0.006 & i & 51 & 273 & 175 \\
\hline 25 & 1.1 & 0.01 & $i$ & 44 & 276 & 243 \\
\hline 26 & 2.4 & 0 & $s$ & 39 & 277 & 226 \\
\hline 27 & 1.1 & 0 & $s$ & 34 & 278 & 252 \\
\hline 28 & 1.0 & 0 & $s$ & 45 & 278 & 254 \\
\hline 29 & 1.3 & 0 & $s$ & 45 & 282 & 253 \\
\hline 30 & 2.2 & 0 & $s$ & 36 & 283 & 231 \\
\hline 31 & 0.8 & 0 & $s$ & 30 & 287 & 265 \\
\hline 32 & 2.7 & 0 & $s$ & 42 & 291 & 231 \\
\hline 33 & 3.1 & 0 & $s$ & 60 & 292 & 221 \\
\hline 34 & 0.1 & 0 & $s$ & 34 & 297 & 281 \\
\hline 35 & 1.2 & 0.003 & $i$ & 19 & 302 & 272 \\
\hline 36 & 0.0 & 0 & $s$ & 30 & 309 & 292 \\
\hline 37 & 2.6 & 0 & $s$ & 51 & 316 & 254 \\
\hline 38 & 1.6 & 0 & $S$ & 23 & 323 & 282 \\
\hline
\end{tabular}

-:not found s:surface pore i:inside pore.

これより, 試料 $\mathrm{A} の$ 破壊源は, 表面破壊, 内部破壊 とも同一原因と考えられ，強度を支配するのは，破 
壊源となるポアであり，試験片中に存在する位置に より，破壊位置が表面か内部に分れたもの上考えら れる，一方，試料Bでは，破罗源を特定できたもの は，半数の 20 試験片であり，曲げ強度が低いもの が多かった，破壊源は，表面部に 17 点，表面より 少し内部の部分で 3 点見いだされた、試料 Bで破壊 原因を発見できなかったものは，曲げ強度が高いも のが多かった，また，Fig.1の試料Bのワイブルブ ロットによると，破壊源が 2 種存在することを示唆 していた。これらのことから，試料Bでは，翼なる 2 つの破壊原因が混在していると考えられる.

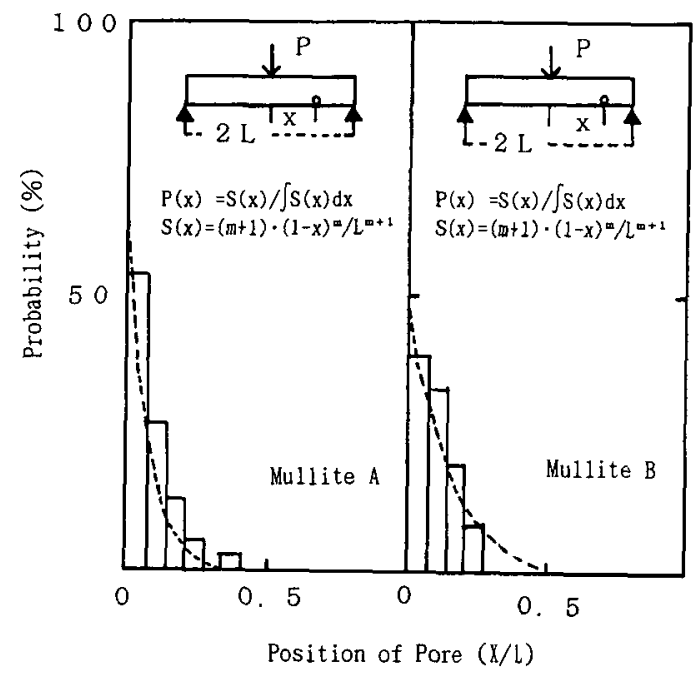

Fig. 3 Distribution of Defect.

ここで，試料Aおよび試料 Bの破壊源位置の測定結 果をFig.3に示す. 試料Aおよび試料 B とも破壊源 は, 原点(荷重負荷直下部の引張り面)の表面近傍 に多く存在するが, 引張り面の広範囲な部分に存在 し，原点から離れるにしたがって隇少することがわ かった，また（2）式で求めた $P(X)$ 上実測值 は，よく対応しており，ワイブル係数が大きいほど 原点から離れて破壊源が存在する確率が低くなった。 従って，本結果の様に破壊源が原点以外に存在する 場合は，破罗源に作用する応力は，原点に破壊源が あるとして計算した 3 点曲げ強度より小さいはずで ある、そこで, Table 2 の破壊位置の実測値を用い, 2.3 に示す応力計算により，曲げ強度 $\left(\sigma_{3 \mathrm{P}}\right)$ を, 破壊位置での応力値 $\left(\sigma_{\mathrm{c}}\right)$ に換算した。試料 $\mathrm{A}$, 試料 B についての計算結果をTable 2 とFig. 4 に示
す.なおFig. 4 には, $\sigma_{3 \mathrm{P}} / \sigma_{\mathrm{c}}=1,1.1,1.2,1.3 の$ 直線をあわせてのせた。試料 $\mathrm{A}$ ，試料 $\mathrm{B} の$ 各試料之 も破塄位置での応力值は，3点曲げ試験で得られた 曲げ強度より $10 \sim 20 \%$ 程度低いものがほとんよ゙ であった，従って，今回作製した破壊源がムライト 試料中に散在するポアである場合，ムライトセラミ ックスの破壊位㯰での応力值は，曲げ強度の測定值 の約 $80 〜 90 \%$ となるとが分かった.

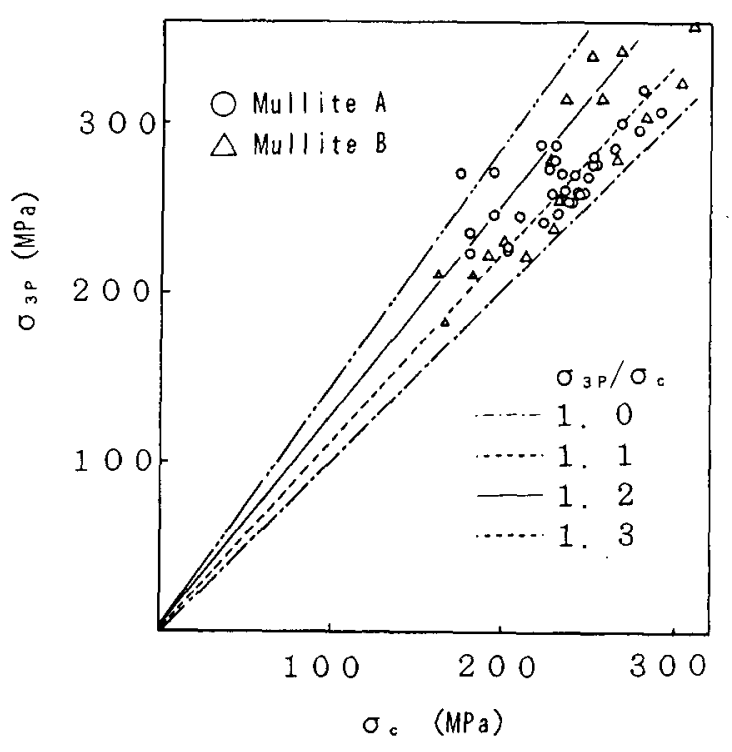

Fig. 4 Relation between Bending Strength and Stress on the defect.

3. 2 曲げ強度と欠樎寸法

グリフィスによれば，ガラス等の脆性材料の強度は， 欠宿寸法（C）の $1 / 2$ 粪に逆比例する，そこで，今回 得られたムライトセラミックス試料 $\mathrm{A}$, 試料 Bにつ いて，実測した破壊源の大きさ（C）の1/2乗と曲げ 強度の関係及び $\mathrm{C}^{1 / 2}$ 之破壊位置のでの応力值との関 係をFig.5に調べた。試料 $\mathrm{A}$ ，試料 $\mathrm{B}$ と破壊鞋性 值は，1.9MPam ${ }^{1 / 2}$ であるので，（3）のグリフィ スの式から破壊応力を求めると, $\sigma=1070 / C^{1 / 2}$ と なる，一方，Fig.5より，曲げ強度とC ${ }^{1 / 2}$ の間には， $\sigma=1710 / \mathrm{C}^{1 / 2}$ となる実験式が得られた、ただし， 士20\%程度のバラツキが認められる，雨式を比較す ると，実験式は，グリフィスの式同様，破壊強度は， 欠宿寸法 (C) の $1 / 2$ 乗に逆比例するが，同一欠宿寸 法における破断強度がグリフィスの式から求まる破 壊強度に比べ，大きい値となることが分かった。 
一方，破壊源の応力換算值と $\mathrm{C}^{1 / 2}$ の間には， $\sigma=$ $1420 / \mathrm{C}^{1 / 2}$ となる実験式が得られ，曲げ強度を用い た場合に比へて，若干バラツキは小さくなった，曲 げ強度および破壊源での応力換算値を用いた実験式 とグリフィスの式とを比較すると，破壊源の応力換 算値を用いた実験式の方が，よりグリフィスの式か ら得られる破壊強度に近かった，グリフィスの式は， 欠陷寸法之破壊応力の関係を示しており，実験結果 とグリフィスの式を比較する場合，破壊源の応力換 算値を用いた方が望ましい，したがって，ムライト セラミックスの破壊源の応力換算値己破壊愿の大き さの関係を示す実験式が，グリフィスの式に近くな った結果は，ムライトセラミックスの場合の破壊強 度と欠附寸法の間には，グリフィスの関係が成立す

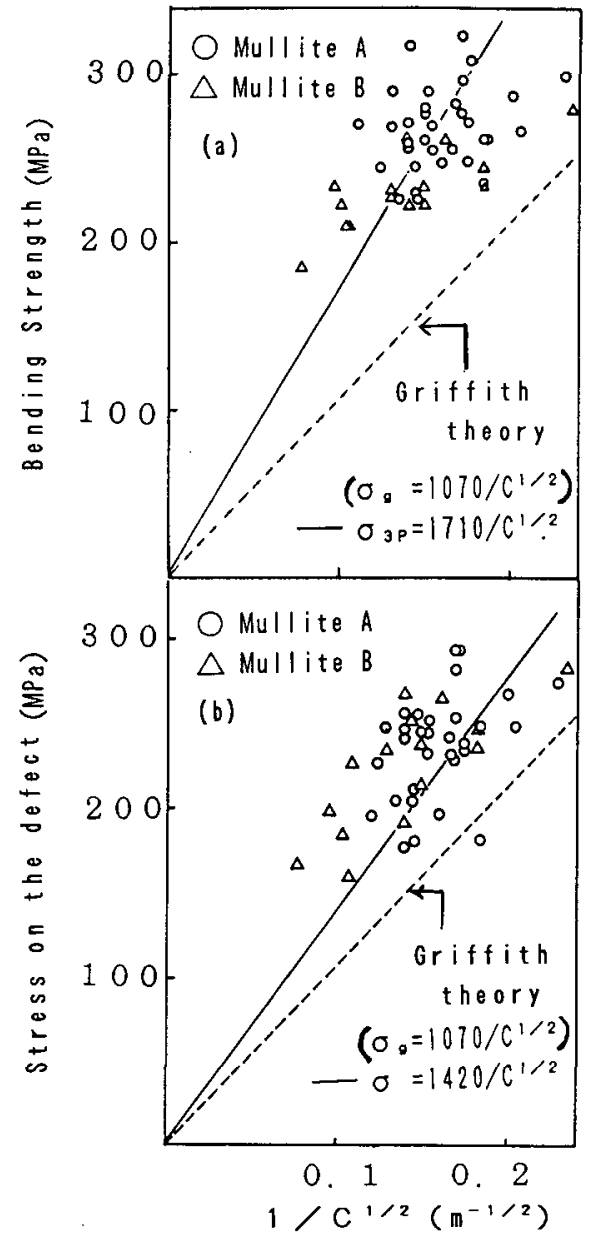

Fig. 5 Effect of defect size on Bending Strength and Stress on the defoct.

(a) Bending Strength (b) Stress on the defect
ることを示していると考えられる.

\section{3 破壊源形状の影響}

3.2 上り，ムライト試料の破壊源の応力値之破壊 源寸法之の間には，グリフィスの式に近い実験式が 得られたが，両式には隔たりがあった。ここで，

（3）式は，破壊源を球形とした式であるが，実際 の破壊源断面を観察すると，不定形であり，棈円形 に近い，破壊源が卵型とすると，曲率半径の小さい 部分に応力が集中し，破壊愿が球のときょり大きな 応力が㗢くと考えられる，そこで，3点曲げ試験に
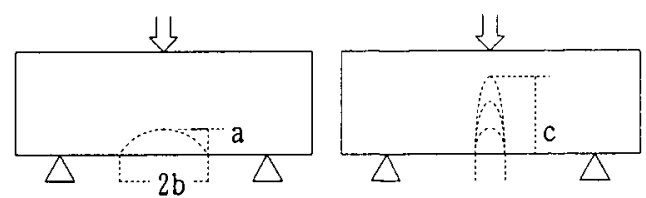

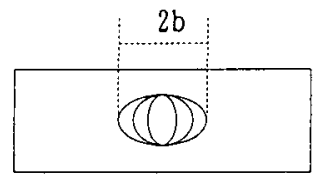

( I )

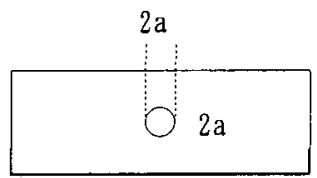

(II)
Fig. 6 Two oval types of defect.

おいて，Fig. 6に示す卵形の破壊源がFig. 1 の原点 に存在するとして，破壊源形状の破壊強度に及ぼす 影響を試算した。ただし，破壊源を卵形とする場合， 試験片に対して破壊源に 2 種の方向が考えられる。 Fig.6-（I ）は，卵形破買源の長径 (2 b) が引張表 面部にある場合の例を短径 (2 a ) を一定として長 径の異なる例を示し，Fig.6-－（II）は，卵形破罗源 の上半分が試験片の下面之垂直に存在する場合を短 径（2 a) を一定として，長径の異なる例を示した. ここで，Fig.6-( I )おるいはFig.6-－（II）の楕円長 径亡短径の比 $b / a ， c / a$ を破壊源の形状係数之 し，負荷荷重に対して発生する最大主応力の比（4） 式を応力集中度と定義した。

\section{応力集中度 $\equiv$ 最大主応力／負荷荷重 （4）}

なお，応力集中度は，破壊源の半径（a）之破 壊源からの距離 $(r)$ の比 $\mathrm{r} / \mathrm{a}$ に依存する量で ある. そこで, 短径 ( 2 a ) を一定とし, $r / a=0$. 1 の位置での応力集中度を計算した. 計算結果を, Fig. 7，Fig. 8に示す.Fig. 7は, Fig.6-(b)の場 合について，棈円短径 (2a) を一定として，cを 
変化させた時の試験片中央部付近の応力分布を示し たものである、Fig．7では，応力分布は試験片の中 央部より左右対称となるので左半分を図示した。

Fig. 7 より最大主応力は，卵形破壊源の先端部に発 生し，c/aが大きくなるつれて堌加したＦig。 8 に形状係数之応力集中度の関係を示す．Fig.7よ り，応力集中度は，形状保数が增加するとともに増 加したが，形状係数が 0.5〜2程度の变化では， 形状係数が 1 の球の場合の応力集中度に対して。

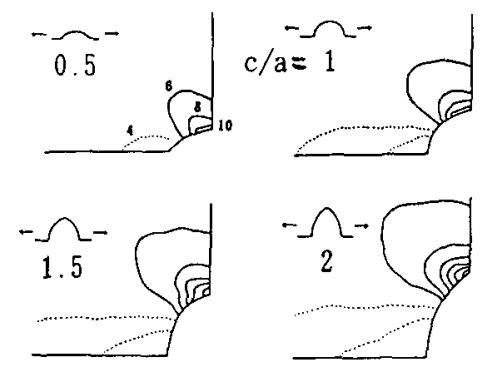

Fig. 7 Isotropic pressure diagram .

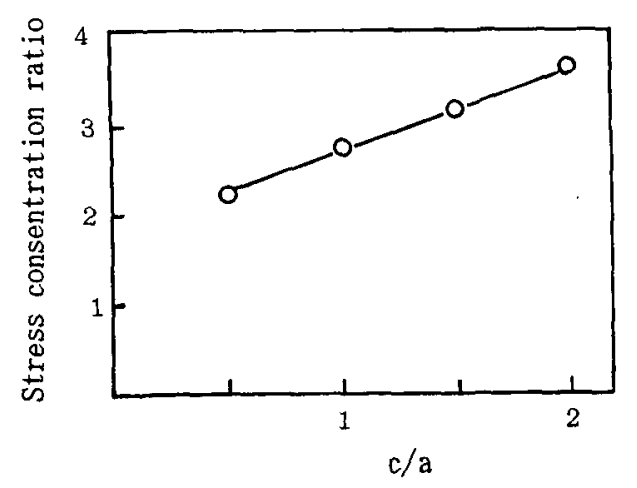

Fig. 8 Relation between $c / a$ and Stress consentration ratio.
-20〜30\%変化することがわかった. 従って, 今回使用したグリフィスの式は，欠陥の形状効果を 考えていないので，グリフィスの式に形状効果とし て，-20〜30\%の破壊応力のバラッキを考虑す る必要があると考える，本計算結果より，グリフィ スの式に破塄源の形状の異方性を考虑すると今回得 られたムライトセラミックスの破壊源における仙力 亡欠宿寸法の間には，グリフィスの式に近い関係が 得られたと考えられる，但し，今回の解析では，欠 陥先端のプロセスゾーンの影響については考虑して いないので，今後検討する必要があると考える。

\section{4 結言}

ムライトセラミックスの3点曲げ強度の原因とな る主な欠楩は，試験片中に多数存在するポアであり， ポアの位置は，試験片ごよに異なり，形状は，不定 形であった，曲げ強度を欠俢部に㗢く応力のに換算 すると，その応力は，曲げ強度の80〜90\%程度 となった，准部に働く応力と欠俩寸法との間には， $\sigma=1420 / C^{1 / 2}$ となる実験式が得られた，実験式の 傾きは，球形欠陉を仮定してグリフィスの式で求め た $\sigma=1070 / \mathrm{C}^{1 / 2}$ よりも大きく，同一応力での欠宿 寸法は，実測の欠陷寸法の方がグリフィスの式から 予測される欠陥寸法上り小さくなった，破壊源形状 を卵型とし，その長径/短径比 $0.5 〜 20$ 䡉囲にお ける久陷にかかる応力集中度は，球型欠陥にかかる 劸集中度の $\pm 30 \%$ 增減することがわかった。

\section{文献}

1) 鈴木弘茂編 : 高温セラミックス材料 日刊工業, (1985) 323 .

2）大橋一利：破壊のメカニズム 丸善，(1987）93 